\title{
EFFECT OF GAMMA IRRADIATION ON THE INACTIVATION OF AFLATOXIN B AND FUNGAL FLORA IN PEANUT
}

\author{
Guilherme Prado ${ }^{1,2 *}$; Eliana Pinheiro de Carvalho²; Marize Silva Oliveira ${ }^{1}$; \\ Jovita Gazzinelli Cruz Madeira ${ }^{1}$; Vanessa Drummond Morais ${ }^{1}$; Ricardo Ferracini Correa ${ }^{3}$; \\ Valbert Nascimento Cardoso ${ }^{4}$; Thaís Veloso Soares; \\ Juliana Fonseca Moreira da Silva ${ }^{5}$; Rúbia Carolina Pereira Gonçalves ${ }^{6}$
}

${ }^{1}$ Divisão de Vigilância Sanitária, Fundação Ezequiel Dias, Belo Horizonte, MG, Brasil. ${ }^{2}$ Departamento de Alimentos, Universidade Federal de Lavras, Lavras, MG, Brasil. ${ }^{3}$ Laboratório de Medidas Nucleares, Centro de Desenvolvimento de Tecnologia Nuclear, Belo Horizonte, MG, Brasil. ${ }^{4}$ Laboratório de Radioisótopos, Faculdade de Farmácia, Universidade Federal de Minas Gerais, Belo Horizonte, MG, Brasil. ${ }^{5}$ Fundação Ezequiel Dias, Belo Horizonte, MG, Brasil.

This paper corresponds to an "extended abstract" selected for oral presentation in the $22^{\text {nd }}$ Brazilian Congress of Microbiology, held in Florianópolis, SC, Brazil, in November 17-20, 2003

\begin{abstract}
The effect of gamma irradiation on aflatoxin $B_{1}$ levels and fungal infection were investigated in peanut samples, Tatu Vermelho cultivar. At a radiation dose of $10 \mathrm{KGy}$, growth of molds was completely inhibited. Doses of 15, 20, 25 and $30 \mathrm{KGy}$ were sufficient for destruction of aflatoxin $\mathrm{B}_{1}$ by $55-74 \%$. The results suggested that the decontamination of molds by irradiation, before production of aflatoxin $\mathrm{B}_{1}$, is the most acceptable method in the preservation of peanut.
\end{abstract}

Key words: peanut, gamma irradiation, aflatoxin $\mathrm{B}_{1}$.

\section{INTRODUCTION}

Aflatoxins are metabolities of the molds Aspergillus flavus, Aspergillus parasiticus and Aspergillus nomius which can grow on a wide variety of agricultural commodities and induce undesirable effects (2).

Different methods have been applied to reduce molds in food, such as fumigation and heat treatment, but none of these methods offers a complete control for toxigenic molds (1).

In september 1997 a Study Group appointed by WHO concluded that "foods treated with doses greater than $10 \mathrm{KGy}$ can be considered safe and nutritionally adequate when produced under established Good Manufacturing Practice" $(4,7)$.

The present study has been conducted to investigate the efficacy of gamma irradiation $\left({ }^{60} \mathrm{CO}\right)$ for the decontamination or inactivation of fungi and aflatoxin $\mathrm{B}_{1}$ occurring in peanut, genotype Tatu Vermelho.

\section{MATERIALS AND METHODS}

\section{Sampling}

The study was carried out analysing three peanut samples (Arachis hypogaea $\mathrm{L}$.) of the Tatu Vermelho cultivar, during the 2003 harvest, of the São Paulo state, Brazil. One sample (A) was naturally contaminated with $248.0 \mu \mathrm{g} / \mathrm{Kg}$ aflatoxin $\mathrm{B}_{1}$ and another (B) with $86.0 \mu \mathrm{g} / \mathrm{Kg}$ aflatoxin $\mathrm{B}_{1}$. In the third sample (C) the aflatoxin $\mathrm{B}_{1}$ was not detected.

\section{Direct Platings}

Peanut seeds of the sample $\mathrm{C}$ were externally disinfected by immersion in a $0.4 \%$ sodium hypochlorite solution for $2 \mathrm{~min}$

*Corresponding author. Mailing address: Fundação Ezequiel Dias. Rua Conde Tereira Carneiro, 80, Gameleira. 30510-010, Belo Horizonte, MG, Brasil. E-mail: gui@funed.mg.gov.br 
and then a total of 50 seeds, in four replications, was plated directly (5 particles per plate) onto Dichloran rose bengal chloramphenicol agar (DRBC). The plates were incubated at $25^{\circ} \mathrm{C}$ for 5-7 days, then inspected for colony growth visually (8).

\section{Gamma-Irradiation}

Samples A e B were packed into polyethlene pouches and irradiated, in three replications, with doses of 0, 15, 20, 25 and 30 $\mathrm{KGy}$ by using ${ }^{60} \mathrm{CO}$ source. Sample $\mathrm{C}$ was packed into polyethlene pouches and irradiated, in four replications, with doses of $0,1,5$ and $10 \mathrm{KGy}$ by using ${ }^{60} \mathrm{CO}$ source, too.

\section{Determination of Aflatoxin $B_{1}$}

A thin layer chromatographic (TLC) method was used for the detection of aflatoxin $B_{1}(9)$.

\section{Statiscal Analysis}

The multiple range test described by Duncan (5) was used to test for statistically significant differences $(\mathrm{p}<0.05)$.

\section{RESULTS AND DISCUSSION}

The effect of different doses of gamma-irradiation in the percentage infection by fungi is shown in Table 1. The data showed that the percentage infection decreased significantly ( $\mathrm{p}<0.05$ ) by increasing the radiation dose levels from 5 to 10 $\mathrm{KGy}$ and the molds were completely inhibited at irradiation dose of $10 \mathrm{KGy}$.

Table 2 shows the effect of different doses of gammairradiation on aflatoxin $\mathrm{B}_{1}$ levels. The results showed that treatment of peanut seeds with gamma irradiation $(15,20,25$ and $30 \mathrm{KGy}$ ) destroyed $69-74 \%$ of aflatoxin $\mathrm{B}_{1}$ in sample $\mathrm{A}$ and $55-62 \%$ in sample B. Farag et al (6) found that the gamma rays even at $20 \mathrm{KGy}$ were not effective in destroying completely the aflatoxins since $83 \%$ reduction was achieved. Recently, Aziz and Youssef (3) showed that a dose of $20 \mathrm{KGy}$ was sufficient for complete destruction of aflatoxin $\mathrm{B}_{1}$ in peanut, yellow corn, wheat and cotton seed meal.

Table 1. Effect of gamma irradiation in infection percentage of peanut seeds.

\begin{tabular}{cc}
\hline $\begin{array}{c}\text { Radiation Dose } \\
(\text { KGy })\end{array}$ & Population $(\boldsymbol{\%})^{\mathbf{1}}$ \\
\cline { 2 - 2 } 0 & Sample C \\
1 & $24 \mathrm{a}$ \\
5 & $21 \mathrm{a}$ \\
10 & $6 \mathrm{~b}$ \\
\hline
\end{tabular}

${ }^{1}$ Values are means of four replicates. Values within treatments followed by the same letter are not signifficantly different $(\mathrm{p}<$ $0,05)$ by the Duncan multiple range test.
Table 2. Effect of gamma - irradiation on the natural occurrence of aflatoxin $B_{1}$ in peanut.

\begin{tabular}{|c|c|c|}
\hline \multirow{2}{*}{$\begin{array}{l}\text { Radiation Dose } \\
\text { (KGy) }\end{array}$} & \multicolumn{2}{|c|}{$\begin{array}{c}\text { Aflatoxin } B_{1}(\mu \mathrm{g} / \mathrm{Kg})^{1} \\
\text { Sample }\end{array}$} \\
\hline & $\mathbf{A}$ & B \\
\hline 0 & $248.0 \mathrm{a}$ & $86.0 \mathrm{a}$ \\
\hline 15 & $65.0 \mathrm{~b}$ & $38.6 \mathrm{~b}$ \\
\hline 20 & $69.0 \mathrm{~b}$ & $33.0 \mathrm{~b}$ \\
\hline 25 & $69.0 \mathrm{~b}$ & $29.6 b$ \\
\hline 30 & $78.0 \mathrm{~b}$ & $33.0 \mathrm{~b}$ \\
\hline
\end{tabular}

1.Values are means of three replicates. Values within treatments followed by the same letter in the vertical line are not signifficantly different $(\mathrm{p}<0.05)$ by the Duncan multiple range test.

\section{ACKNOWLEDGEMENTS}

The authors thank the Fundação de Amparo à Pesquisa do Estado de Minas Gerais and CNPq for financial support and the Santa Helena Industry of Foods by the samples of peanut.

\section{RESUMO}

\section{Efeito da irradiação gama na inativação da aflatoxina $B_{1}$ e flora fúngica em amendoim}

$\mathrm{O}$ efeito da irradiação gama nos níveis de aflatoxina $\mathrm{B}_{1}$ e na infecção fúngica foram investigadas em amostras de amendoim, cultivar Tatu Vermelho. Dose de irradiação gama $\left({ }^{60} \mathrm{Co}\right)$ de 10 KGy inibiu completamente o crescimento de fungos. Doses de $15,20,25$ e $30 \mathrm{KGy}$ foram suficientes para destruição de aflatoxina $\mathrm{B}_{1}$ de 55 a $74 \%$. Pode-se concluir do presente trabalho, que a descontaminação de fungos por irradiação gama antes da produção de aflatoxina $\mathrm{B}_{1}$ é o método apropriado na preservação de amendoim.

Palavras-chave: amendoim, irradiação gama, aflatoxina $\mathrm{B}_{1}$.

\section{REFERENCES}

1. Aziz, A.N.; Attia, E.S.A.; Farag, S.A. Effect of gamma-irradiation on the natural occurrence of Fusarium mycotoxins in wheat, flour and bread. Nahrung., 41:34-37, 1997.

2. Aziz, N.H.; Abd El-Rehim, L.M.; El-Far, F.M.A. Effect of gammairradiation on aflatoxin $\mathrm{B}_{1}$ produced by Aspergillus parasiticus in barley containing antimicrobial food additives. Egypt. J. Rad. Sci. Applic., 12:101-116, 1999.

3. Aziz, N.H.; Youssef, B.M. Inactivation of naturally occurring of mycotoxins in some egyptian foods a and agricultural commodities by gamma-irradiation. Egypt. J. Food Sci., 30:167177, 2002.

4. Bruyn, I.N. The application of high dose food irradiation in South Africa. Rad. Phys. Chem., 57:223-225, 2000.

5. Duncan, B.B. Multiple range and multiple F-tests. Biometrics., 11:142, 1955. 
6. Farag, R.S.; Rashed, M.M.; Hussein, A.A.; Abo-Hagar, A. Effect of gamma radiation on the infected yellow corn and peanuts by Aspergillus flavus. Chem. Mikrobiol. Technol. Lebensm., 17:93-98, 1995.

7. Lara, J.; Fernández, P.S.; Periago, P.M.; Palop, A. Irradiation of spores of Bacillus cereus and Bacillus subtilis with electron beams. Inn. Food Sci. Emerg. Techn., 3:379-384, 2002.
8. Pitt, J.I.; Hocking, A.D. Fungi and food spoilage. 2nd ed. Blackie Academic and Professional, London, 1997.

9. Soares, L.M.; Rodriguez-Amaya, D.B. Survey of aflatoxins, ochratoxin A, zearalenone and stergmatocystin in brazilian foods by using mult-toxin thin layer chromatographic methods. J. Assoc. Off. Anal. Chem., 73:22-26, 1989. 